\title{
Generosity and Cooperation Across the Life Span: A Lab-in-the-Field Study
}

\author{
Supplementary information (SI) \\ Angelo Romano, Stefania Bortolotti, Wilhelm Hofmann, \\ Matthias Praxmarer, and Matthias Sutter*
}

* To whom correspondence should be addressed. E-mail: Matthias.Sutter@coll.mpg.de 
Contents

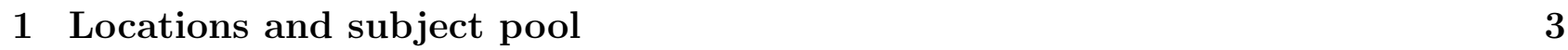

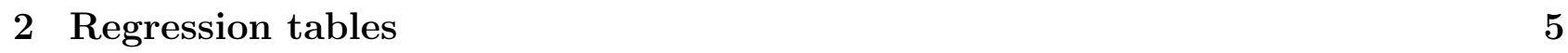

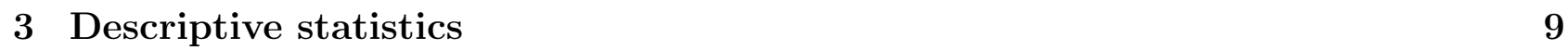

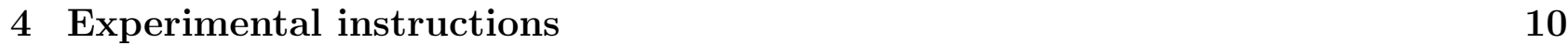




\section{Locations and subject pool}

The lab-in-the-field experiment was conducted in Austria (8.7 million inhabitants), and more precisely in Tyrol (746,000 inhabitants), one of the 9 federal states. The shopping malls are located in smaller towns (10,000 - 15,000 inhabitants), and the senior fair took place in Innsbruck (Figure 1, panel a). The first shopping mall has more than 70 stores and 7,000-10,000 customers per day, while the second shopping mall has 40 shops. Even though the two shopping malls are located in relatively small towns, they attract customers from several neighboring towns. This granted us the possibility to recruit a varied sample of people resident in about 20 different towns/villages: hence reducing the chances that participants knew each other. The senior fair in 2016 was organized over three days and had 9,000 visitors. In each location, we had banners to advertise the study (Figure 1, panel b) and we set up an experimental desk were the payments were carried out.

Supplemental Figure 1: Experimental locations

(a) Map

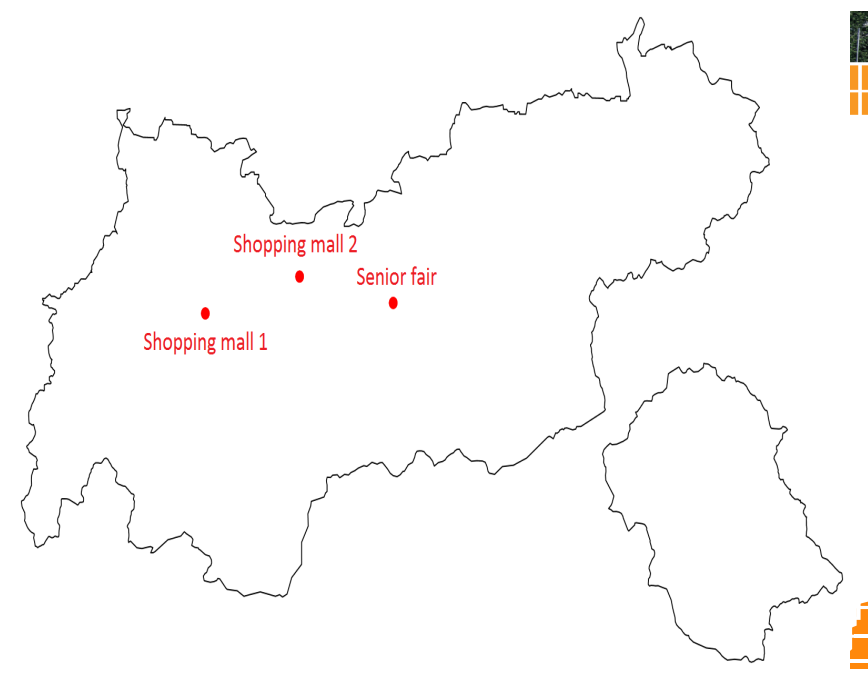

(b) Banner

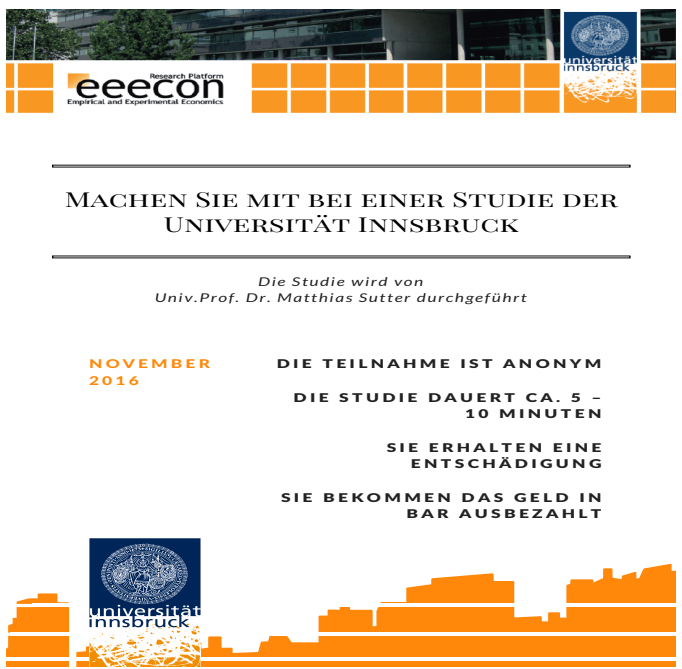


Supplemental Table 1: Socio-demographic characteristics of the subject pool

\begin{tabular}{|c|c|c|c|c|c|c|}
\hline & \multicolumn{3}{|c|}{ Our sample } & \multicolumn{3}{|c|}{ Austrian Population } \\
\hline & $\begin{array}{c}\text { Young } \\
\text { 18-39 years }\end{array}$ & $\begin{array}{c}\text { Middle } \\
\text { 40-59 years }\end{array}$ & $\begin{array}{c}\text { Older } \\
\text { 60-90 years }\end{array}$ & $\begin{array}{c}\text { Young } \\
\text { 18-39 years }\end{array}$ & $\begin{array}{c}\text { Middle } \\
\text { 40-59 years }\end{array}$ & $\begin{array}{c}\text { Older } \\
\text { 60-90 years }\end{array}$ \\
\hline Share of the adult population $(a)$ & $36.21 \%$ & $30.92 \%$ & $32.87 \%$ & $34.58 \%$ & $35.64 \%$ & $29.78 \%$ \\
\hline Females $^{(a)}$ & $57.69 \%$ & $63.06 \%$ & $54.24 \%$ & $48.95 \%$ & $50.06 \%$ & $55.54 \%$ \\
\hline Average age ${ }^{(a)}$ & 28 years & 50 years & 70 years & 29 years & 50 years & 73 years \\
\hline \multicolumn{7}{|l|}{ Education $^{(b)}$} \\
\hline High school & $33.08 \%$ & $27.03 \%$ & $25.42 \%$ & $34.81 \%$ & $29.24 \%$ & $22.61 \%$ \\
\hline Bachelor degree or more & $24.62 \%$ & $25.23 \%$ & $22.88 \%$ & $17.82 \%$ & $14.97 \%$ & $7.75 \%$ \\
\hline \multicolumn{7}{|l|}{ Employment status $^{(c)}$} \\
\hline Employee & $74.62 \%$ & $75.68 \%$ & $9.32 \%$ & $77.22 \%$ & $70.95 \%$ & $5.43 \%$ \\
\hline Self-employed & $3.85 \%$ & $6.31 \%$ & $5.93 \%$ & $4.96 \%$ & $10.71 \%$ & $1.76 \%$ \\
\hline Residents in Innsbruck & $12.31 \%$ & $10.81 \%$ & $29.66 \%$ & - & - & - \\
\hline
\end{tabular}

Notes: All data for Austrian refer to the adult population. Sources: (a,b) "Statistics Austria" - the federal statistical office of Austria - and (c) "Eurostat." Last data check: 23 ${ }^{\text {rd }}$ May, 2018. (a) Population statistics refer to year 2018. (b) Education data refer to year 2014. Due to data availability, the Young cohort is defined over the interval 20-39 years. (c) Employment data refer to the 2011 Census.

Our enumerators were instructed to approach passersby and invite them to participate in a research study organized by the University of Innsbruck. In the recruitment process, we tried to limit as much as possible the participation of multiple family members by inviting only one of them to the study. We also ensured that nobody took part in the study more than once. Enumerators were asked to try to approach people from different age cohorts. A total of 359 subjects participated in our study (Table 1). 344 participants filled in all the items of the Dictator and Prisoner's Dilemma Game (cooperative and dictator choices plus beliefs), while 15 failed to complete one or more items 1 In the analysis, we always use all the available data for the specific question at hand. As a result, the number of observations might change from one test to the other.

\footnotetext{
${ }^{1}$ The number of participants who failed to complete the experiment in all its parts is similar across age cohorts (6 for Young, 5 for Middle, and 4 for Older).
} 


\section{Regression tables}

Supplemental Table 2: Generosity and Cooperation over the life span

\begin{tabular}{|c|c|c|c|c|}
\hline & \multicolumn{2}{|c|}{$\begin{array}{l}\text { Generosity in } \\
\text { Dictator Game }\end{array}$} & \multicolumn{2}{|c|}{$\begin{array}{c}\text { Cooperation in } \\
\text { Prisoner's Dilemma }\end{array}$} \\
\hline & Model 1 & Model 2 & Model 3 & Model 4 \\
\hline Age (in years) & $\begin{array}{l}0.023^{* * *} \\
(0.007)\end{array}$ & $\begin{array}{l}0.019^{*} \\
(0.010)\end{array}$ & $\begin{array}{r}0.001 \\
(0.001)\end{array}$ & $\begin{array}{r}-0.001 \\
(0.001)\end{array}$ \\
\hline \multicolumn{5}{|l|}{ Socio demographics } \\
\hline Male $(1=$ Yes, $0=N o)$ & & $\begin{array}{r}0.081 \\
(0.258)\end{array}$ & & $\begin{array}{r}-0.030 \\
(0.038)\end{array}$ \\
\hline Number of children & & $\begin{array}{r}0.047 \\
(0.127)\end{array}$ & & $\begin{array}{r}0.031 \\
(0.019)\end{array}$ \\
\hline \multicolumn{5}{|l|}{ Education } \\
\hline High School $(1=$ Yes, $0=$ No $)$ & & $\begin{array}{r}0.057 \\
(0.316)\end{array}$ & & $\begin{array}{r}0.010 \\
(0.046)\end{array}$ \\
\hline College $(1=$ Yes, $0=$ No $)$ & & $\begin{array}{r}0.428 \\
(0.325)\end{array}$ & & $\begin{array}{r}0.072 \\
(0.047)\end{array}$ \\
\hline Education N.A. $(1=Y e s, 0=N o)$ & & $\begin{array}{r}-0.081 \\
(0.521)\end{array}$ & & $\begin{array}{r}-0.082 \\
(0.081)\end{array}$ \\
\hline \multicolumn{5}{|l|}{ Location } \\
\hline Resident in Innsbruck ( $1=$ Yes, $0=\mathrm{No}$ ) & & $\begin{array}{r}0.261 \\
(0.412)\end{array}$ & & $\begin{array}{r}0.015 \\
(0.061)\end{array}$ \\
\hline Shopping mall 1 ( $1=$ Yes, $0=N o$ ) & & $\begin{array}{r}0.005 \\
(0.434)\end{array}$ & & $\begin{array}{r}0.067 \\
(0.061)\end{array}$ \\
\hline Senior fair $(1=$ Yes, $0=$ No $)$ & & $\begin{array}{r}0.290 \\
(0.404)\end{array}$ & & $\begin{array}{r}0.072 \\
(0.059)\end{array}$ \\
\hline \multicolumn{5}{|l|}{ Order effect } \\
\hline Prisoner's Dilemma first $(1=Y e s, 0=N o)$ & & $\begin{array}{r}0.236 \\
(0.390) \\
\end{array}$ & & $\begin{array}{r}0.037 \\
(0.055)\end{array}$ \\
\hline Dummies for helpers & No & Yes & No & Yes \\
\hline Constant & $\begin{array}{l}3.210^{* * *} \\
(0.345)\end{array}$ & $\begin{array}{l}3.057^{* * *} \\
(0.690)\end{array}$ & & \\
\hline $\begin{array}{l}\text { N.obs. } \\
R^{2} \text { (overall) }\end{array}$ & $\begin{array}{r}1067 \\
0.022\end{array}$ & $\begin{array}{r}1043 \\
0.039\end{array}$ & 1067 & 1043 \\
\hline
\end{tabular}

Notes: Models 1 and 2 report coefficients of panel random-effects GLS regressions. The dependent variable is the amount given to recipients in the Dictator Game. Models 3 and 4 report marginal effects obtained from panel random-effects logit regressions. The dependent variable assumes 1 for cooperation and 0 for defection in the Prisoner's Dilemma. The Age (in years) of the dictator (Dictator Game)/decision maker (Prisoner's Dilemma) is the main independent variable. Further independent variables include Socio demographic variables Male (assumes 1 for male and 0 for female) and Number of Children. Moreover, we control for Education with three dummy variables for different education levels: High School, Bachelor or more (College), N.A. in case the information is not available. The baseline category for education is Vocational training or lower. In addition, we include 3 control variables for the Location. The first location control variable controls if the participant is a Resident in Innsbruck (assumes 1 if yes and 0 if no). Both other location variables control for the location where the experiment took place: Shopping mall 1 (assumes 1 if yes and 0 if no) and Senior fair (assumes 1 if yes and 0 if no). The baseline category is Shopping mall 2. Finally, we also control for potential Order effects with the dummy variable Prisoner's Dilemma first (assumes 1 if a participant first played the Prisoner's Dilemma and 0 if a participant first played the Dictator Game). Standard errors in parentheses. Significance levels: ${ }^{* *} \mathrm{p}<0.001,{ }^{* *} \mathrm{p}<0.01,{ }^{*} \mathrm{p}<0.05$. 
Supplemental Table 3: Generosity conditional on the age cohort of the partner

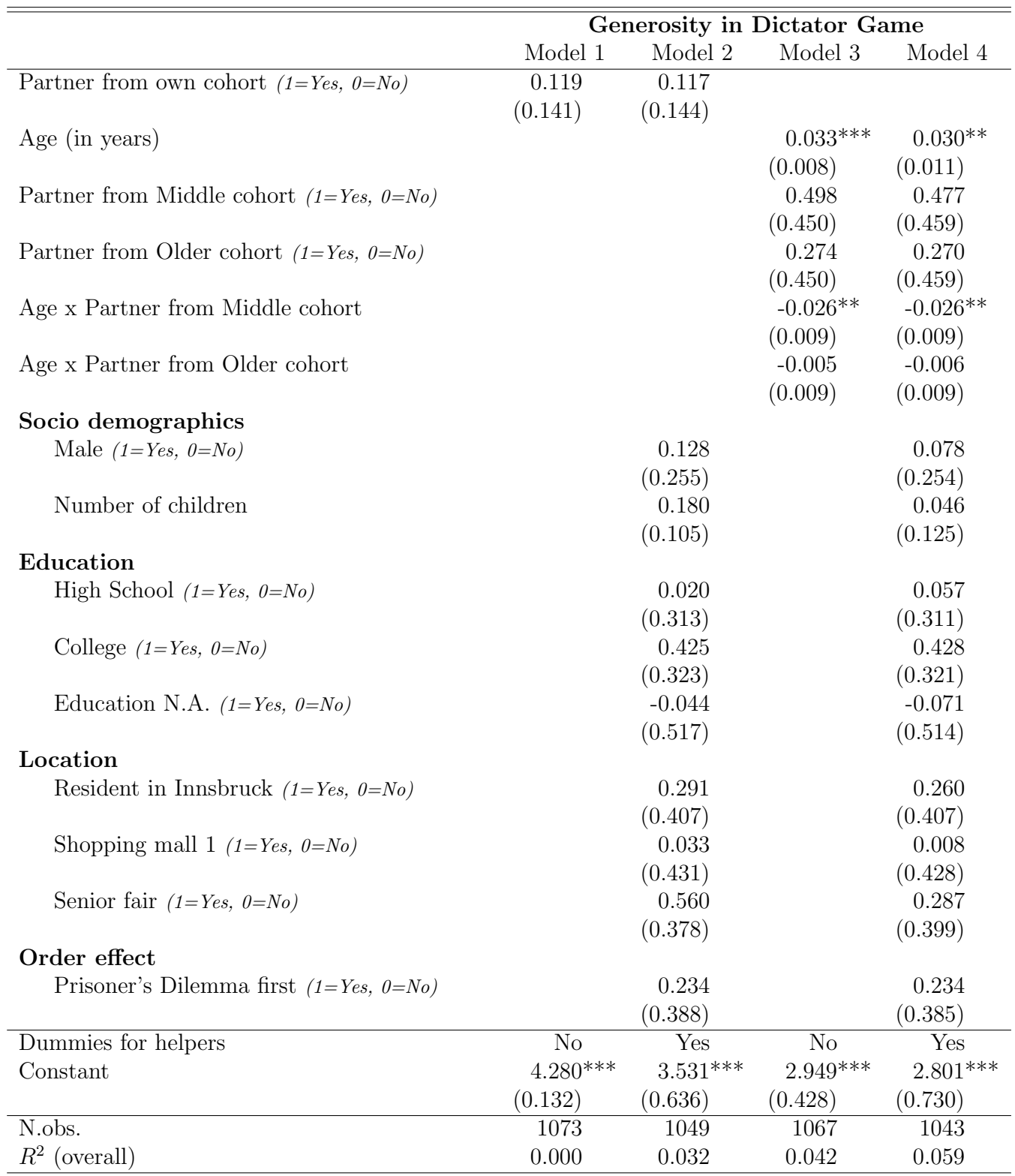

Notes: Models 1 to 4 report coefficents obtained from panel random-effects GLS regressions. The dependent variable is the amount given to recipients in the Dictator Game. The main independent variable in Models 1 and 2 is Partner from the own cohort which assumes the value 1 if the partner is from the same age cohort and 0 otherwise. The main independent variables in Models 3 and 4 are Age (in years) of the dictator and two dummies for the partner cohort, Partner from the Middle cohort (assumes 1 if the partner belongs to the Middle cohort and 0 otherwise) and Partner from the Older cohort (assumes 1 if the partner belongs to the Older cohort and 0 otherwise). Baseline is that the partner belongs to the Young cohort. The last two main independent variables of interest are the two interaction terms of Age (in years) and both partner cohort dummies. See notes of Supplemental Table 2 for a detailed description of the other independent variables. Standard errors in parentheses. Significance levels: ${ }^{* *} \mathrm{p}<0.001,{ }^{* *} \mathrm{p}<0.01,{ }^{*} \mathrm{p}<0.05$. 
Supplemental Table 4: Cooperation conditional on the age cohort of the partner

\begin{tabular}{|c|c|c|c|c|}
\hline \multirow{3}{*}{ Partner from own cohort $(1=$ Yes, $0=N o)$} & \multicolumn{4}{|c|}{ Cooperation in Prisoner's Dilemma Game } \\
\hline & Model 1 & Model 2 & Model 3 & Model 4 \\
\hline & $\begin{array}{c}-0.039 \\
(0.025)\end{array}$ & $\begin{array}{r}-0.037 \\
(0.025)\end{array}$ & & \\
\hline Age (in years) & & & $\begin{array}{c}0.004^{* *} \\
(0.001)\end{array}$ & $\begin{array}{r}0.001 \\
(0.002)\end{array}$ \\
\hline Partner from Middle cohort $(1=Y e s, 0=N o)$ & & & $\begin{array}{c}0.192^{* *} \\
(0.064)\end{array}$ & $\begin{array}{l}0.189^{* *} \\
(0.065)\end{array}$ \\
\hline Partner from Older cohort $(1=Y e s, 0=N o)$ & & & $\begin{array}{l}0.195^{* *} \\
(0.069)\end{array}$ & $\begin{array}{c}0.205^{* *} \\
(0.069)\end{array}$ \\
\hline Age x Partner from Middle cohort & & & $\begin{array}{l}-0.004^{* *} \\
(0.002)\end{array}$ & $\begin{array}{l}-0.004^{* *} \\
(0.002)\end{array}$ \\
\hline Age x Partner from Older cohort & & & $\begin{array}{r}-0.003 \\
(0.002)\end{array}$ & $\begin{array}{l}-0.003^{*} \\
(0.002)\end{array}$ \\
\hline Socio demographics & & & & \\
\hline Male $(1=$ Yes, $0=N o)$ & & $\begin{array}{r}-0.037 \\
(0.038)\end{array}$ & & $\begin{array}{r}-0.030 \\
(0.038)\end{array}$ \\
\hline Number of children & & $\begin{array}{r}0.022 \\
(0.016)\end{array}$ & & $\begin{array}{r}0.030 \\
(0.019)\end{array}$ \\
\hline Education & & & & \\
\hline High School $\left(1=Y e s, 0=N_{o}\right)$ & & $\begin{array}{r}0.017 \\
(0.046)\end{array}$ & & $\begin{array}{r}0.010 \\
(0.046)\end{array}$ \\
\hline College $(1=$ Yes, $0=$ No $)$ & & $\begin{array}{r}0.074 \\
(0.047)\end{array}$ & & $\begin{array}{r}0.071 \\
(0.047)\end{array}$ \\
\hline Education N.A. $(1=Y e s, 0=N o)$ & & $\begin{array}{r}-0.079 \\
(0.081)\end{array}$ & & $\begin{array}{c}-0.082 \\
(0.081)\end{array}$ \\
\hline Location & & & & \\
\hline Resident in Innsbruck ( $1=Y e s, 0=N o$ ) & & $\begin{array}{r}0.020 \\
(0.061)\end{array}$ & & $\begin{array}{r}0.015 \\
(0.061)\end{array}$ \\
\hline Shopping mall $1\left(1=\right.$ Yes, $\left.0=N_{o}\right)$ & & $\begin{array}{r}0.065 \\
(0.061)\end{array}$ & & $\begin{array}{r}0.067 \\
(0.061)\end{array}$ \\
\hline Senior fair $(1=Y e s, 0=N o)$ & & $\begin{array}{r}0.050 \\
(0.056)\end{array}$ & & $\begin{array}{r}0.072 \\
(0.059)\end{array}$ \\
\hline $\begin{array}{l}\text { Order effect } \\
\quad \text { Prisoner's Dilemma first }(1=Y e s, 0=N o)\end{array}$ & & $\begin{array}{r}0.038 \\
(0.055)\end{array}$ & & $\begin{array}{r}0.037 \\
(0.055)\end{array}$ \\
\hline Dummies for helpers & No & Yes & No & Yes \\
\hline N.obs. & 1073 & 1049 & 1067 & 1043 \\
\hline
\end{tabular}

Notes: Models 1 to 4 report marginal effects obtained from panel random-effects logit regressions. The dependent variable assumes 1 for cooperation and 0 for defection in the Prisoner's Dilemma. The main independent variable in Models 1 and 2 is Partner from the own cohort which takes the value 1 if the matched partner is from the same age cohort as the decision maker and 0 otherwise. The main independent variables in Models 3 and 4 are Age (in years) of the dictator and two dummies for the partner cohort, Partner from the Middle cohort (assumes 1 if the partner belongs to the Middle cohort and 0 otherwise) and Partner from the Older cohort (assumes 1 if the partner belongs to the Older cohort and 0 otherwise). Baseline is that the partner belongs to the Young cohort. The last two main independent variables of interest are the two interaction terms of Age (in years) and both partner cohort dummies. See notes of Supplemental Table 2 for a detailed description of the other independent variables. Standard errors in parentheses. Significance levels: *** $\mathrm{p}<0.001,{ }^{* *} \mathrm{p}<$ $0.01, * \mathrm{p}<0.05$. 
Supplemental Table 5: Cooperation and Expectations by the age of the decision maker

\begin{tabular}{lcrc}
\hline \hline & \multicolumn{3}{c}{ Cooperation in the } \\
& \multicolumn{2}{c}{ Prisoner's Dilemma } \\
& The partner belongs \\
& \multicolumn{2}{c}{ to the ... cohort } \\
& Young & Middle & Older \\
\hline Expect Cooperation $(1=Y e s, 0=N o)$ & $0.526^{* * *}$ & 0.253 & $0.510^{* * *}$ \\
Age of decision maker (in years) & $(0.081)$ & $(0.170)$ & $(0.134)$ \\
Age x Expect Cooperation & $0.004^{* *}$ & -0.001 & 0.002 \\
& $(0.002)$ & $(0.002)$ & $(0.002)$ \\
N.obs. & -0.005 & 0.004 & -0.001 \\
& $(0.003)$ & $(0.002)$ & $(0.002)$ \\
\hline
\end{tabular}

Notes: The table reports marginal effects obtained from logit regressions by the age cohort of the matched partner. The main independent variables include Expect cooperation which takes the value 1 if the decision makers stated that she/he expects the partner from the relevant cohort to cooperate and 0 otherwise. Further, we add a variable for the age of the decision maker (in years). The last independent variable of interest is the interaction term of Expect cooperation and the age of the decision maker (in years). Significance levels: ${ }^{* * *} \mathrm{p}<0.001,{ }^{* *} \mathrm{p}<0.01,{ }^{*} \mathrm{p}<0.05$. 


\section{$3 \quad$ Descriptive statistics}

Supplemental Table 6: Summary statistics of the Dictator Game

\begin{tabular}{|c|c|c|c|}
\hline \multirow{2}{*}{$\begin{array}{l}\text { Age cohort of } \\
\text { the DM }\end{array}$} & \multicolumn{3}{|c|}{ Age cohort of the recipient } \\
\hline & Young & Middle & Older \\
\hline Young & $\begin{array}{c}4.16 \\
(269)\end{array}$ & $\begin{array}{c}3.74 \\
(2.46)\end{array}$ & $\begin{array}{c}4.28 \\
(289)\end{array}$ \\
\hline Middle & $\begin{array}{c}4.54 \\
(2.92)\end{array}$ & $\begin{array}{c}3.89 \\
(2.58)\end{array}$ & $\begin{array}{c}4.30 \\
(2.90)\end{array}$ \\
\hline Older & $\begin{array}{c}5.03 \\
(3.23)\end{array}$ & $\begin{array}{c}3.84 \\
(3.01)\end{array}$ & $\begin{array}{c}5.17 \\
(3.43)\end{array}$ \\
\hline
\end{tabular}

Notes: The table shows the mean amount given (standard deviation in parentheses) for each age cohort of dictators conditional on the age cohort of the recipient.

Supplemental Table 7: Summary statistics of the Prisoner's Dilemma Game

\begin{tabular}{lccc}
\hline \hline $\begin{array}{c}\text { Age cohort of } \\
\text { the DM }\end{array}$ & \multicolumn{3}{c}{ Age cohort of the partner } \\
Young & Middle & Older \\
\hline \multirow{2}{*}{ Young } & 0.55 & 0.67 & 0.70 \\
& $(0.50)$ & $(0.47)$ & $(0.46)$ \\
Middle & 0.65 & 0.63 & 0.67 \\
& $(0.48)$ & $(0.48)$ & $(0.47)$ \\
Older & 0.68 & 0.59 & 0.68 \\
& $(0.47)$ & $(0.49)$ & $(0.47)$ \\
\hline
\end{tabular}

Notes: The table shows the fraction of cooperators (standard deviation in parentheses) for each age cohort conditional on the age cohort of the partner. 


\section{Experimental instructions}

Page 1$]^{2}$

\section{General information}

Thank you very much for participating in this short study. You can earn money during the study and we will pay in cash and in private at the end of the study. Please, read the instructions carefully because your decisions can influence your earnings and the earnings of other people. You will be able to participate in two games.

\section{Instructions Game 1}

We will form pairs and one member of the pair will be randomly assigned $€ 10$ and the other $€ 0$. At the end, we will determine if you get the $€ 10$ or the other member of the pair by a coin flip.

If you are ready you can turn the page. You have to answer to Part A first and can then move to Part B.

If you have any question during the experiment, please ask a member of the staff.

\section{$\underline{\text { Page } 2}$}

\section{Decisions Game 1: Part A}

Consider the case in which you win the coin flip and get $€ 10$.

You have to decide if and how much you want to give to the other person. You can condition the amount on the age group of the other person. You will know the actual age only at the end. If you win the coin flip, your earnings are equal to 10 minus what you give to the other person.

How much would you like to give to the other person?

You can give any amount between 0 Euro and 10 Euro, in increments of 50 cents.

\begin{tabular}{cc}
\hline \hline $\begin{array}{c}\text { Age range of the } \\
\text { other person }\end{array}$ & $\begin{array}{c}\text { Give to the } \\
\text { other person }\end{array}$ \\
\hline $18-39$ years & .......... Euro \\
$40-59$ years & .......... Euro \\
60 years + & ......... Euro \\
\hline \hline
\end{tabular}

\footnotetext{
${ }^{2}$ The design was presented in a A5 format booklet. The original instructions are in German and are available upon request from the authors.
} 


\section{Decisions Game 1: Part B}

Consider the case in which you

lose the coin flip and get $€ 0$.

You have to state how much you expect to receive from the other member of the pair. You can condition your answer on the age group of the partner. You also have to choose the age group of the person you want to be paired with.

How much do you think the other person would give you?

With whom do you want to be paired?

Remember that the sum of the money the other person keeps and gives to you must be 10 Euro. Please round the amounts to the nearest 50 cents.

\begin{tabular}{ccc}
\hline \hline $\begin{array}{c}\text { Age range of the } \\
\text { other person }\end{array}$ & $\begin{array}{c}\text { Receiving from } \\
\text { another person }\end{array}$ & $\begin{array}{c}\text { Choose with whom (age } \\
\text { range) you want to be } \\
\text { matched with } \\
\text { [ONLY ONE ANSWER] }\end{array}$ \\
\hline $\begin{array}{c}18-39 \text { years } \\
40-59 \text { years }\end{array}$ & $\ldots \ldots \ldots \ldots$ Euro & O \\
60 years + & $\ldots \ldots \ldots .$. Euro & O \\
\hline \hline
\end{tabular}

$\underline{\text { Page } 4}$

\section{Instructions Game 2}

In this part of the experiment, you receive 2 Euros and will be matched with another participant (different from the one in Game 1).

You have to decide between two actions: Keep or Transfer.

- If you Keep, you keep the 2 Euros and the other participant receives nothing from you.

- If you Transfer, you send the 2 Euros to the other participant and he/she receives 4 Euros.

The other participant is playing the same game as you, and can either Keep or Transfer. There are four possible cases:

1. Both you and the macht Keep: both earn 2 Euro.

2. You Keep and your match Transfer: you earn 6 Euro and your match earns 0 Euro

3. Both you and your match Transfer: both earn 4 Euro

4. You Transfer and your match Keep: you earn 0 Euro and your match earns 6 Euro 
If you have any question during the experiment, please ask a member of the staff.

Page 5

\section{Decisions Game 2}

Please make your decision.

Now you have to decide if you choose to Keep or Transfer. You can condition your answer on the age group of the partner. You also have to state what do you expect from your match. Do you think the person matched with you will Keep or Transfer? (you can condition on the age of the other person)

Please mark your choices with an X.

\begin{tabular}{cll}
\hline \hline $\begin{array}{c}\text { Age range of the } \\
\text { other person }\end{array}$ & Your decision & $\begin{array}{l}\text { What do you expect } \\
\text { from the person } \\
\text { matched with you? }\end{array}$ \\
\hline \multirow{2}{*}{$18-39$ years } & $\begin{array}{l}\text { O Transfer } \\
\text { O Keep }\end{array}$ & $\begin{array}{l}\text { O Transfer } \\
\text { O Keep }\end{array}$ \\
\hline \multirow{2}{*}{$40-59$ years } & O Transfer & O Transfer \\
& O Keep & O Keep \\
\hline \multirow{2}{*}{60 years +} & O Transfer & O Transfer \\
& O Keep & O Keep \\
\hline \hline
\end{tabular}

Page 6

\section{Questionnaire}

Age (in years):

Gender:

O Male

Place of residence (Zip code):

O Female

Highest education level attained:

Number of children:

Employent:

(Please choose one):

O Employee

O Self-employed

O Unemployed

O Student

O Housewife

O Retired

$\mathrm{O} \mathrm{N} / \mathrm{A}$ 